Michael Roper

\title{
Chapter 6 -- Subjectivities in the aftermath: children of disabled soldiers in Britain after the Great War
}

In her memoir Under My Skin, Doris Lessing writes that:

I used to joke that it was the war that had given birth to me, as a defence when weary with the talk about the war that went on - and on - and on. But it was no joke. I used to feel there was something like a dark grey cloud, like poison gas, over my early childhood. Later I found people who had the same experience. Perhaps it was from that war that I first felt the struggling panicky need to escape, with a nervous aversion to where I have just stood, as if something there might blow up or drag me down by the heel. ${ }^{1}$

This chapter is concerned with the impact of the First World War on children like Lessing (born 1919) whose fathers were disabled veterans. At the end of the war there were more than 750,000 permanently disabled soldiers in Britain and by 1929, 1.6 million men were in receipt of a war pension. ${ }^{2}$ Their problems were psychological as well as physical: almost twenty years after the conflict, 35,000 pensions were being paid out to ex-servicemen with mental disabilities. ${ }^{3}$ As historians are now discovering, however, the extent of disability among First World War veterans was far greater than these figures indicate, as not all veterans suffering from war-related conditions received pensions, while others developed health problems later in life that could not be directly attributed to their military service. ${ }^{4}$ But the impact of war disability extended further than even these revised estimates suggest, for as Lessing intimates above, it was not just the veteran, but families who lived with the physical, economic and psychological legacies of a war wound. Despite being born after the conflict's end, for Lessing the war felt part of her very being, her amputee father's depression, and the 
stress that living with and caring for him placed on her mother (who had been his nurse during the war), being taken in from birth like a form of poison gas.

What follows is based on an ongoing oral history project about the impact of the First World War on the generation born between 1918 and the mid-1930s. The interviewees were in their late eighties and nineties at the time of interview and were drawn from regions across the UK including the cities of Bristol, Middlesbrough and Cambridge, and rural regions of Norfolk and Essex. ${ }^{5}$ Of the thirty-five people interviewed so far, thirteen had fathers with war-related disabilities which included mental health problems, complete or partial blindness, loss of limbs and war-related health conditions such as TB and rheumatic fever. Two of the fathers had never been officially recognised as war disabled and did not receive a pension. Eight of the thirteen fathers had been unable to work and their children had grown up in comparatively poor circumstances, though some went on to have successful careers themselves. Taking Lessing's cue, this chapter investigates how the children's lives were affected by their father's situation and the nature of his disability. Part one discusses parental and gender roles, for if disability could pose challenges to the status of fathers and husbands as men, at the same time, as Jessica Meyer has observed, it could pressure wives and mothers into "often unwanted emancipation from traditional gender roles." " Part two focuses on the interviewee's accounts of their relationships with fathers and mothers, and how their experience of disability shaped the ties across generations. Part three reflects on how disability challenged generational norms of care.

The disruptions in gender and generational norms, the stresses in getting by financially and in managing the day-to-day running of the household, and the experience of being close to suffering - woken at night by a father's nightmare, feverish rant, or cry of pain - made these children alert to how their parents were coping. Helping their parents and not complaining, keeping a 'stiff upper lip' and not becoming absorbed in their own troubles, was 
expected and approved by parents and relatives. ${ }^{7}$ These were common emotional dispositions within households of the poor and unskilled working-class in Britain in the first half of the twentieth-century, which were absorbed in getting by. ${ }^{8}$ However, these scripts could take on particular intensity in the families of disabled soldiers, being a source of pride for the children and even part of a family myth of resilience. The returned soldier's plight tended to take centre-stage while the children's subjectivities were shaped in the wings.

Studies of the First World War are beginning to address the kinds of issues raised here about the impact of disability across generations. Until recently historians of war disability have tended to adopt, in Marina Larsson's words, a "soldier-centred approach." They have focused on topics like medical treatment, war pensions, and national differences in provision. ${ }^{9}$ The 'more contextual' aspects of disability, including the impact on veterans' families, have been less well understood. ${ }^{10}$ Larsson's oral history study of the families of Australian veterans, Shattered Anzacs is a notable exception, arguing as it does that "[p]lacing the family at the centre of historical analysis opens up new possibilities for writing histories of 1914-18 and its aftermath." ${ }^{11}$ While for Larsson the family unit provides the lens through which to view disablement, I am concerned with the implications of war disability for the second generation.

Research on Holocaust survivors and their families has led to the development of a field concerned with the psychological impact of war across generations. Dan Bar-On, Ilany Kogan, Marianne Hirsch and others have investigated how experiences of humiliation, shame and loss - which survivor parents were often unable to vocalise- were, in the face of silence, passed to the children in various forms of unconscious enactment. ${ }^{12}$ Kogan identifies two ways in which the trauma of survivors may be passed on. "Primary identification" refers to the sensitivity which the children of survivors may develop towards the suffering of the parent. They tend to possess a deep sense of responsibility towards their parents, and feelings 
of guilt when they cannot help. They develop a heightened awareness of the parent's needs and dependence. Another way in which trauma may cross generations is through the emotions that the traumatised parent lodges unconsciously in the child. The second generation become repositories for unbearable feelings which the survivors project into their children. In acting as a container for the parents' trauma, the children themselves become vulnerable to psychic damage. ${ }^{13}$

In these studies, the psychological mechanisms of transmission tend to be regarded as universal. The assumption is that the intergenerational impact of a trauma will have recognisable features - such as 'primary identification' and projective identification - despite variations in time, culture and the war experience of parents. My study is based on an older cohort, whose childhoods were shaped between the wars rather than after 1945, but when interviewing I sometimes recognised the emotional states described in this literature. For example, I sometimes felt the sensation of what Haydeée Faimberg calls "the telescoping of generations," a foreshortening of time where the interviewees became deeply immersed in a past that was not their own. ${ }^{14}$ In the middle of my interview with Ashcroft she suddenly exclaimed, "It's my mother's life that's interesting!"15 The feeling of being dominated by a parent's experience is common to the second generation, but at the same time, testimonies like Ashcroft's also bear the interwar imprints of region, social class, gender, and social expectations surrounding emotion. These too have shaped the legacies of the war transmitted across generations and to me as an interviewer, and I will mention two here.

Firstly, their testimonies reveal the impact of interwar social policies concerning veterans. Pension provision for disabled ex-servicemen in Britain, although generous by domestic standards, was poor by the standards of both Germany and France. Deborah Cohen estimates that between 1925 and 1930 war pensions took up around 20\% of the annual German budget, compared with just 7\% in Britain. British war pensions were largely 
intended to supplement earnings, officials sought to limit government obligations with regular reviews of the veteran's functioning, and the state did not provide training for reintegration into civilian life. ${ }^{16}$ Voluntary organisations like the charity for blind veterans, St Dunstan's, and the British Limbless ex-serviceman's Association (BLESMA) sought to fill the gap but the extent of support depended partly on the type of disability, as some war wounds had a higher public profile than others. St Dunstan's was particularly successful and was able to help set men up in new occupations: they supplied Ainsley's father in law with coconut fibre to make matting, and Borden's father was set up with a poultry farm. ${ }^{17}$ Starr, whose father was a double amputee and grew up in a South London complex for disabled veterans and their families, envied the children of St Dunstan's men because they went out on day trips, got gifts at Christmas, and gained free admission to football matches. ${ }^{18}$ Voluntary provision was uneven, however. Rural dwellers tended to be less well served, and as Cohen notes, charitable aid often came with moral strings attached. ${ }^{19}$ The parsimony of the state and the patchy reach of the voluntary sector meant that disabled ex-servicemen and their families often depended primarily on their own members and neighbours for help. The effects on the children were indirect but could be far-reaching: eighty years on, around half the interviewees were still living in the region where they grew up, an indication perhaps of the kinds of family cultures that developed in response to the typically restricted mobility of the disabled veteran.

Financial hardships affected the emotional climate of family life. The two interviewees in this study perhaps least affected by their father's circumstances were from middle-class backgrounds. One father had lost his leg and the other had heart problems caused by rheumatism, but their needs were accommodated by their civil service employers. Others blamed their family's economic hardships on the state, the sense of injustice (sharpened by comparison with the recent treatment of disabled veterans from the Iraq and 
Afghanistan wars) being an important motivation for the interview. When I asked Ashworth why she had contacted me, she explained:

MA: I just thought it might do some good, because I feel very bitter that my mother didn't get a pension, and I thought if somebody - that that actually did happen somebody might do something about it. I don't know whether they do that now or not, but that was the law then.... She married after he was wounded. If she'd have married him before, she'd have had the full pension all the time we were little. And I thought it might do some good that way, that was all.... Because it isn't fair. She even had a letter... from ... er ... the Army doctor to somebody, that said, "This man is swinging the lead". ${ }^{20}$

"That actually did happen," Ashcroft says, as if the fact that her mother did not receive a pension might be difficult for younger people to fathom, having lived with the protection of a welfare state. ${ }^{21}$ Her attitude reflects a public legacy of relatively weak state provision and political passivity among disabled veterans in Britain between the wars, and a private, domestic legacy of anger towards the Ministry of Pensions. ${ }^{22}$ The 'primary identifications' of the children were conditioned by scarcity and the post-war settlement for disabled soldiers.

The emotional codes of interwar Britain were also different from those that surrounded childhood after the Second World War. As Hera Cook has argued, restraint and endurance were hallmarks of interwar English culture, and would become, during the Second World War, keys to national identity and survival. Some interviewees described families in which it was felt best not to give in to strong emotions. When Ashcroft's eldest brother Eric was killed in a plane crash at the end of the Second World War, little more than a decade after her father, her mother cried for two days. But as Ashcroft explained proudly, she never stopped working: 
I mean, she was cooking and doing everything, she didn't give into it, but she was just crying as she walked around. But ... er ... and I ... all I can remember ... I have great difficulty in crying, I always have had. As a kid I had. But I can remember waking up next morning, every morning for ages after, and my cheeks were stiff with salt. I couldn't ... I must have cried all the time I was asleep, because I worshipped him - he was my father. I hadn't had a father for a long time, and he took the ... the $\ldots$ and he was a lovely lad. ${ }^{23}$

In this passage Ashcroft moves from describing how her mother bore up to grief, to reflect on her own grief, which she explains came out when she was asleep and the conscious controls on emotion were lifted. As the inter-generational studies of trauma suggest, this is a psychological process: the mother's striving to hold things together is enacted in her daughter's difficulties crying. Ashcroft's grief over the death of her father becomes part of how she experiences the loss of her brother, who steps into the father's role to such an extent that, at first, it was unclear to me which man she was recalling. Yet these psychological processes of identification and transmission articulate with particular historical structures of feeling. Faced with economic stresses consequent on disability, for many families "control was necessary to survival." ${ }^{24}$ Ashcroft's trouble crying was not only a psychic enactment of her mother's efforts to manage her grief, but enacted a widely held social creed that it was better to try and keep control over one's emotions. In the next section I will explore further the way in which disability placed the gender and emotional scripts of motherhood and fatherhood under stress, and the impact this had on children.

\section{The emotional scripts of parenting}

Disability often placed conventional gender roles and expectations of marriage under stress. For a start, the children were often growing up in households where the father was 
unemployed or not able to work full-time. In the children's eyes his identity was shaped by not being a breadwinner. Ashcroft had no memory of her father going out to work. She thought he might have been a miner but wasn't sure. Prescott kept a photograph of her bedridden father, with his wife and nurse - his two carers - standing at the bedside. Starr's father lost both his legs during the war, and in the only photograph that Starr possesses of him prior to the war, he holds a baker's cart and appears barely more than a boy. Although the children of more severely incapacitated soldiers did not know their fathers as breadwinners, at the same time these men were more present in the home than many fathers, and this could give rise to positive memories. ${ }^{25}$ Ashcroft remembered her father coming to meet her after school and jumping out of shop doorways to surprise her. He was kind and affectionate:

... I never went to bed without he said, "Good night, me old love!" He'd give me a kiss - I can remember that vividly. And I can remember my mother made everything. But a treat was a bought cake - to us - because we never had ... there was a bakery at the end of the road, and they sold butterfly cakes with fresh cream in, and I remember I was off school, ill, and because I was ... and my dad was in bed ill - one of his ill times - and I got into bed with him during the day, and my mother had brought my dad a butterfly cake ... er ... as a treat, because, as I say, they were treats. And he gave it to me, and I remember her coming in and saying, "Oh, love, I was giving you a treat", and he says, "Let her have it, she'll enjoy it better than me". ${ }^{26}$

Having a sick father at home gave the children opportunities for play and intimacy, but it also meant that they were exposed to his wounds, and, at times, his pain. The tender moments that Ashcroft recalls were with a man who was dying of a particularly horrific cancer:

we lived in a little cottage, so there was no privacy, as you can imagine, and I can remember the nurse coming to dress it regularly. He had a hole right round there 
[points to the area around her mouth and cheek]. One day I found a baked bean inside his mouth... it [the cancer] gradually ate his face away till he had a haemorrhage when it hit his main artery here, and that was when he died - that was my ninth birthday. ${ }^{27}$

In a society where occupation and physical strength were important signifiers of masculinity, and where, despite the increase in 'male domesticity', breadwinning continued to be a key aspect of fatherhood, the children's feelings about having an incapacitated, stay-at-home father could be quite complex, as we will see below. ${ }^{28}$

Disability had equally complicated implications for wives and mothers. On the one hand it underscored wartime ideals of women as nurses. Women were encouraged to marry disabled soldiers, and the nurse provided a model of the kind of 'generous self-sacrificing woman' that the wife of the disabled soldier was supposed to be. ${ }^{29}$ Many interviewees reported on the care undertaken by mothers. A husband's wounds might need tending to, like Ashcroft's father who preferred his wife rather than the nurse to dress his face. Some wives worked as nurses or VADs in the war, like Doris Lessing's mother, and Borden's mother, whose marriage to his blind father was semi-arranged. He needed a wife to help him run the poultry farm, and had written to his old nurse at St Dunstan's to ask if she knew of someone eligible.

On the other hand, disability could compromise patriarchal authority and push wives into unconventional roles, taking responsibility for earning money and doing tasks around the home that a husband would normally do. Pudney's mother had started a successful grocer's business while managing the domestic work and care of her four children and was a successful family breadwinner. The womanly work of caring could entail gender reversals, as this account by Prescott reveals. Early on in our interview she became upset when 
remembering the decline in her father's health. She and her sisters had come home from school for lunch: "we were having our dinner, and my mum heard him come [coughs] to the top of the stairs, and he wanted to come down, and she used to carry him about, and she carried him down and sat him in his chair while we had ... I went in there from school, you know, and ... he ... you still go through all these things." ${ }^{30}$ The memory of her father's frailty is sharpened by the gender reversals that his situation had necessitated. Pleading like a child from the top of the stairs, he depended on her mother's physical strength to get about the house. Prescott's story symbolises the dependent passivity of the wounded veteran, which was a cause of distress for the children as they watched their fathers and mothers trying to cope.

\section{Relationships with fathers}

From an early age the interviewees had become mindful of their father's disability. If he was blind or had lost a leg, he might trip up if toys were left strewn around; doors had to be kept fully open or closed so blind fathers would not walk into them. In his worse moments, which might be for days or weeks at a time, they had to keep quiet. Adjusting their behaviour in this way, it could almost come to feel as if the disability was their own. ${ }^{31}$ The children developed a double subjectivity: sensitive to the world that their fathers had to negotiate, they had their own feelings about his disability. Five minutes into my interview with Borden, he related a memory of meeting his blind father on the way back from school in winter. As he spoke he switched back and forth between describing the things his father was able to do, and recalling his own feelings as a child. In the winter dusk, the young Borden experienced something like the unsighted world of his father:

RB: Erm ... he was ... found his way around the farm all right. And I remember when I went to school, in the local school, he would walk along the lane, sort of meet 
me coming home, sort of as it was getting dark in the winter time. I don't think I was, you know, too pleased about doing that, but it was only a sort of straight lane ...

MR: You mean you weren't pleased about him doing that?

RB: Yes. I wasn't pleased about me being, you know, out there alone!

MR: Okay.

RB: It was dark.... So he did that. ${ }^{32}$

At points, Borden recalls the journey from his father's point of view, suggested in his reference to how he was able to walk unassisted down the lane because it was a "straight line." The blind veteran who could "walk alone" was considered to be the epitome of the war hero, and perhaps Borden wishes to convey something of this in his story, but he then switches to a personal memory of feeling discomfited by the dark, possibly even afraid of the figure feeling his way towards Borden in the gloom. ${ }^{33}$ This reveals the flipside of the red badge of courage identity, the fearfulness of impairment. ${ }^{34}$ Borden concludes the description by returning to the theme of how the disability affected his father ("So he did that.")

Oscillations like this between the 'I' and the 'he' suggest how vestiges of the children's feelings then can surface in the interstices as they talk about how their fathers coped with disability.

Children were sometimes disturbed by the sight of wounds. Meeks recalled the bees swarming around his father's amputated arm while he was at work on their smallholding, attracted by the smell. The re-appearance of amputated veterans from more recent conflicts threw Starr back to his feelings as a child:

BS: I know when I used to see them, I didn't like the look of them! (laughs) They looked horrible! 
MR: No. Can you describe what they were like?

BS: Er ... erm ... well, you know, there was just the stump, with a sort of loose end. You know, you've seen pictures of them coming back from Afghanistan ... well, you know, it puts me off when I see that - the young blokes now doing the same. And that's how it is, you know, two short stumps ... that was all it was. Yeah. Yeah. ${ }^{35}$

The sense of horror is conveyed in Starr's fixation on the stump, his desire to convey to me what was missing from his father's body, that that was "all it was."

Fathers' wounds might not only be frightening to look at; their habits could be embarrassing. But the children could not easily voice feelings like these. Pudney's father had suffered a series of strokes when Pudney was a teenager which "affected his eating. He'd invariably dribble, and drop stuff out of his mouth, which was unpleasant ... but then, that was how he did it, and ... you know, we didn't take notice of - that was ... that was Dad, and that's how he lived. And so we just used to accept that in the family." 36 That was just how it was, says Pudney, but the vivid memory of his father's difficulties eating suggests that did indeed "take notice."

Having a father whose mobility was restricted could mean that the children's mobility was also restricted. This had implications for sons in particular, as fathers could not play sport or engage in other physical activities. Starr remembered the stultifying routines of his early life. His double-amputee father would sit for hours on end "in a wooden armchair ... erm ... it was quite a good effective chair, but that was all., ${ }^{, 37}$ Starr would play crib with him ("I've never had a pack of cards since he died...") and family outings were restricted to Sundays, the same weekly ritual of walking over Battersea bridge to the park. ${ }^{38}$ Starr felt he had lost out through not having had a father who could do practical things, as he had been hopeless with DIY, and had only learned to ride a bike when he joined the Army. Starr was 
hesitant to mention these things - it clearly felt disloyal to his father - but he spoke with a tinge of regret.

Some of these children, although they lived with their fathers about the house, felt that they had grown up without a paternal presence. They had had fathers, but had not been fathered. Maloney talked about how, after his breakdown, his father became "the butt of jokes and fun." He was called Father Christmas because of his long white beard. For a boy to have a father who was a figure of fun must have been humiliating. On one occasion Maloney's school friends had seen his father when passing by the house and had assumed he was his grand-father. As Maloney reflected guiltily; "I never disabused them of that." 39 After his breakdown the veteran had, in effect, lost the right to fatherhood, a loss for both father and son. As Maloney explained,

Now, I had a father, but could never be taken as a father in the full sense of the word ... engaging. There was nobody to say, you know, "Come along, I'll show you how to fish", you know, "Let's go and have a kick about with the football". You know, "What do you think of Norwich this week, what they done?" No, none of that. Erm ... but when I got married, you see, I just didn't really know what a father's duties were, because ... I ... I know that there was ... you know, affection, and love there even, for me, on his behalf, but that could never be shown. And that's ... that's a big miss. $^{40}$

Living with physical limitations and behaviour which contradicted conventional ideals of fatherhood and masculinity, many interviewees had constructed a counter-image of their father. Two photographs hung side-by-side in the hallway of Maloney's house. One was his father in army uniform, the other a dishevelled and unshaven man. These were the two visions that Maloney retained: "Dad," of whom he had the barest memory, and "Old Larky," the eccentric and embarrassing figure in the kitchen. Elsewhere in the house were photos of 
his father captaining a local football team, and an oil painting by him. His father had been an accomplished piano player ("when he returned from church... people used to stand outside the house and listen to him - he was that good"). Maloney had kept his father's sporting equipment, boxing gloves, dumbbells, and a cricket bat "that were never got rid of for some reason." All other evidence of his father's past had been destroyed: "Mother then decided that the past was the past and should be put behind them, and they must make the best of what they have got, and we don't have a photograph of her or my father before they were married ... erm ... no records, nothing, and it was said that Mother destroyed everything." ${ }^{41}$ In the face of this, the sports equipment, photos and oil painting - objects that signalled his father's accomplishments before the war and his breakdown - had become important keepsakes.

Others also resurrected the image of an able-bodied father. In the first few minutes of our interview Pudney explained proudly how at the age of just 13 , his father was put in charge of a team of horses, something that would normally only occur when a boy reached adulthood. ${ }^{42}$ The remarkable boy posed a stark contrast to the returned soldier:

AP: Went off to France, and he came back weighing 6 stones.

MR: Six stone?

AP: Minus one leg. ${ }^{43}$

Some emphasised how well their fathers had coped with their injuries. Whilst in hospital recovering, Starr's father learned to light his cigarette with his left arm. Meeks's father had insisted that the surgeons must not amputate his arm, telling them that as a nurseryman he could not do without it. After the war he was determined to manage the family smallholdings, and with his arm bound in a leather sling, he found a way to dig, hoe and even build his own chicken coop. Meeks was proud of his father's determination and ingenuity. His four 
siblings were the living proof that, as he put it, "Father wasn't out of action completely, was he!" 44

For Kathleen Scates, the indignity and shame of having a father who had been committed to a mental hospital was countered by an image of his manly virtues as a patient. Because of his long periods in hospital her mother had in effect become the head of household, but in the eyes of the hospital staff he remained a gentleman and paterfamilias:

The hospital welcomed him. They said, 'He's the best man we've had, because he takes all the other men, when they come in ..." - mental cases - they're absolutely frightened to death, they don't know what's going to happen to them, some are belligerent, start to fight ... but he would calm them all down, and they used to put all the new men, in the end, at his table at lunchtime. And he said his prayers before meals. And this ... he sort of made them feel that it was quite normal. And, "Come, Fred, and sit here", and so on, and so Fred sat there for about a month, and then another man came in, and so on, and so he got them used to the routine of the hospital. The hospital thought he was wonderful. ${ }^{45}$

Living amidst injuries that were debilitating and had financial and emotional implications for the whole family, the children often created a kind of alter-image of the father. Working with what they knew of his pre-war history, and observing how he coped with his condition, in their minds they rehabilitated the disabled veteran as a father and man and reinstated his badge of courage.

Idealised images like these could paper over ambivalent feelings. Though he recognised his father's prowess as a farm hand, Pudney praised his mother's abilities as a businesswoman and gave the impression of being much closer to her than to his father. He had been trained as a boot-repairer after the war, but the tiny Norfolk village where they lived 
was too small to support his business and as the family grew they got further into debt. Pudney's mother took charge, setting up a general store with money borrowed from a local family she had known as a child. I was struck by the contrasting fates of his parents in Pudney's narrative. Just as his mother was beginning to make a success of her shop, his father began to suffer from strokes. He became infirm and dependent as she became resourceful and enterprising: 'And so she set into work - it was just early days of the War - and she worked like a demon, worked 12, 15 hours a day, running the shop, looking after the family, keeping things going, and helping my father go about his business. ${ }^{46}$

Pudney thought that the marriage was based on pity rather than love. She was his father's saviour, Pudney explained, 'she was the making of him, and she kept him going all his life', but there was no romantic interest:

He was not the right sort of man for her. They never were suitable. As I got older, of course, I could see that. I would talk to her ... I talked endlessly to my mother, we spent a lot of time together, and we talked endlessly about it, and she'd say, "No, I wouldn't have married Tom", she'd have married one of the blacksmith's boys. She knew who she wanted to marry. They were good friends to her. But she stayed with my father and looked after him, and that's how we lived. ${ }^{47}$

Pudney portrayed his father as a rather semi-detached figure, heading off to the pub in his pony and trap or somewhere in his workshop beside the store. Pudney had been much closer to his mother: "I was my mother's favourite - so I made up for it!" "What do you mean?," I asked, and he replied "Well, my ... my best times, in my early life, was crawling on to my mother's lap, in the evening, having five minutes cuddle, you know, when I was ... what ... 3, 4, 5, 6 - the best time in my young life.” As Pudney saw it, his mother had been motivated by a sense of duty in her care of his father, and love in her care of him. A father's war wound 
could encourage the children to align themselves with the figure upon whose destiny they depended most - the mother.

\section{Relationships with mothers}

Many of the interviewees in the study talked at length about the impact of disability on their mothers. Although from diverse regions and social backgrounds, they expressed the kind of idealised gratitude characteristic of many working-class memoirs of late-nineteenth and early twentieth century childhoods. ${ }^{48}$ They wanted to impress on me the range of their mothers' skills. South explained how his mother used to do the gardening and repairs around the house, as his amputee father was unable to bend down. Maloney's mother made ends meet with little more than her husband's work pension: “Well, I don't know how she managed. Erm ... but we were never starved, but nothing was ever wasted. She was very good."49 Meeks described his mother as "a very energetic person, I mean, it's obvious that with his arm, she did most of the work with the poultry and whatnot, you know." When she wasn't looking after the poultry she was cooking or making mats and rugs to sell. ${ }^{50}$ The interviewees reached for religious metaphors in their efforts to express how much their mothers had done for the family. South, who grew up in a semi-detached house in one of London's commuter suburbs, said of his mother, "I think it was her life's work. She was quite dedicated," and later on, "undoubtedly she ... it was her dedicated life's work to ... to minister unto him, as it were." ${ }^{51}$ A similar image of devotion came to Meeks as he recalled his childhood in a Norfolk village: “Oh, I think Mother ... I don't know, she must have been a saint.,

Tributes like this were a sign of the children's dependence on their mothers, but this could make them anxious as well as grateful. Marion Ashcroft had a recurring fear after her father died. Every afternoon she would pass her auntie's house on the way back from school 
and look to see if the curtains at home were closed. She would think "Oh, my mum hasn't died, because she hasn't drawn the curtains". "The biggest fear I had at that age', she explained, "was when he died - and I was heartbroken because he was a lovely man - was if my mother died. That was the biggest emotion."

As with fathers, the asymmetry in paternal roles had complicated effects on the children, sparking not just admiration for mothers' resourcefulness, and gratitude that home lives had been made bearable due to her efforts, but a range of other emotions too. One point of tension was the pressure that a father's disability placed on daughters to help out. Sons were not exposed to the same kinds of pressures; Starr for example, felt rather guilty because his older sister was expected to help out more than he did. A daughter was also likely to experience more pressure than a son to discontinue her education. Such expectations, and the tensions they aroused, were a feature of the relationships between the daughters of disabled soldiers and their mothers. ${ }^{54}$

Daughters reacted to these pressures in different ways. Harriet Prescott did not appear to feel ambivalent about supporting her mother. After joining up and being posted away during the Second World War, she asked to return home. When the request was refused she got the union involved, telling them that her mother was recently widowed and "still needed me at home," so she was relocated to a munitions factory from where she could commute. She was motivated by the stresses she knew her mother would be facing: "and she was so busy going to work, and then coming home ... and I know me ... me ... and Winnie, she used to bath the two [younger siblings]... she must have been about 12, but we all had to muck in, and sort it out between us. Must have been ... it must have been terrible for my mother ... and sometimes I do have a little weep over it.",55

Others felt a greater sense of conflict. Gates struggled with the sense of responsibility she felt towards her mother after her father's death in 1943 when she was sixteen: "I crossed 
over to being an adult, you know, I wasn't one of the children any more. I had two younger brothers ... erm ... and she relied on me a great deal. But she had to ... she was worried about money, because whatever he had left - I don't know the details - erm ... wasn't really quite enough for her to live on with two boys coming up at grammar school."56 Gates moved back home to complete her teacher training but she did not like being there as her mother had taken in boarders and there was nowhere quiet in the house to study. After graduating she took a teaching job in Birmingham:

There was more freedom. I had more freedom to ... I mean, I was in digs with another girl, and we had the freedom to say ... suddenly say, "We'll go out for the night", you know, "We'll go to the pictures" or something like that. If I'd lived at home, I couldn't have done that, I'd have been ... coerced, or co-opted, perhaps, into helping with the housework, or helping with the student lodgers, or helping with my brothers or something, whereas ... selfishly, I had that more freedom. ${ }^{57}$

As a middle-class daughter, the obligation was still there to help out her mother - Gates at first describes it as coercion, then softens her comment by substituting the word "co-option" but there was also an understanding that education and a career might necessitate mobility, and this gave Gates a reason to leave home. Her sense of guilt, however, was apparent in the interview, three quarters of a century later.

Other daughters tailored their ambitions to their mother's situation. Ashcroft's older brother had won a place at grammar school shortly before their father died. When Ashcroft turned twelve, she also sat the entry examinations: "I passed my first half - you sat it twice, this scholarship to go to grammar school. But there again, you see, this is how it affects a child. I was worried sick for fear I passed, because I knew my mother couldn't afford the uniform." ${ }^{58}$ Her ambitions were curtailed again during the Second World War. She had wanted to join up, but her brother, who was on overseas service with the RAF at the time, 
advised her to keep her job in the local grocers, as this was an exempted occupation which allowed her to live at home. Although disappointed, Ashcroft accepted his advice as the head of the household following their father's death. There were counter-veiling pleasures: "I remember how proud I was to give her ten shillings, and I kept 2/6d., and clothed myself. And ... oh, she was thrilled." 59

The ties between mothers and daughters, intensified by having a disabled soldier at home, could continue into the mother's old age, and some interviewees had chosen to live nearby their mothers or take them into their own homes. In Harriet Prescott's family the patterns established after the First World War have passed across three generations. In 1946 Harriet married an ex-serviceman who had been invalided out of the army due to lung problems. Like her mother, she must have known that his condition was likely to deteriorate and that she might become responsible for his care. Her husband died when he was in his early fifties, and since then, "I've always lived with one of these [pointing to her daughters], and I could ... they all live near one another, and I could go and visit one, and then don't go home, just crawl in bed with one of the kids!"60

Her daughters stayed with Harriet throughout our interview, jogging her memory or contradicting her assertions. There was much hilarity, as mother and daughters ribbed each other about their domestic obsessions. However the light tone changed when Harriet talked about her mother's decision to re-marry. Harriet had strong feelings about the second husband: "I couldn't stand the sight of him. And he come to the door one day, and I was doing the front, and I made him wait at the front door, and I shut the door on him!" Harriet felt that in re-marrying, her mother was being disloyal to the memory of her father ("I suppose if she'd have brought anybody else, I'd have thought just the same, because nobody can take the place of your father."). But it also upset Harriet because it seemed to discount the loyalty she had shown her mother. At one stage she turned to her daughters and said, "And I 
wouldn't have dared bring anybody ... would I?" ${ }^{\circ 1}$ As Elizabeth Roberts has argued, matriarchal relationships such as this were a feature of family life in Northern working-class

towns in the first half of the twentieth century. ${ }^{62}$ For Harriet, who had lived all her life around Middlesbrough area, two generations of war disability had further strengthened the maternal ties, and encouraged inter-dependence between mother and daughters.

\section{Generational Reversals}

In the families of disabled soldiers - particularly the more severely incapacitated - there were constant physical, material and emotional pressures. As they talked about their childhoods, the interviewees expressed what it had felt like to be on the edge of a struggle that had absorbed their parents. Mothering and fathering were one of the many things that parents had to do: looking back as adults, they understood why often they could not be the centre of their parents' attention. At the same time, against the wish to think well of their parents, aspects of the child's sense of discontent or disappointment occasionally surfaced in the interviews. As Ashcroft went through her mother's many gifts, her qualities as a mother seemed at first an afterthought:

My mother was very well-liked, and very well-respected. She used to play a big part in the chapel - or church, if you want to call it, Methodist Church. I can remember her giving talks, and the lesson if the chief one was off. And she played ... she could play any ... any song on the piano, if she could sing it - because she couldn't read a note of music, but she could sit down and ... and she played the organ for them when the organ mistress was off. She was a woman born before her time.

MR: Yes. 
MA: Yes, because today, she would have ... and I'll tell you what she won prizes for.

Er ... painting. She was marvellous at that sort of thing. And she was a good mother, besides that. ${ }^{63}$

Realising that to mention her mother belatedly in this way might appear ungrateful, Ashcroft went on to reiterate what 'a good mother' she had been. ${ }^{64}$ She did not want to leave me with a negative impression. Like many poor children of his generation, Meeks was conscious of the toll taken by his mother in raising himself and his brothers and sisters: “Oh, I think Mother ... I don't know, she must have been a saint. I mean, she put up with us kids, she had kids all the time..." In different ways, the interviewees communicated the contradictory emotional legacies of childhoods lived around disability.

The norms of care were to an extent reversed, as the children learned to become attuned to the emotional states of their parents. I was struck by the way in which Ashcroft related the memory of her father crying out in pain at night. It was the effect on her mother which she emphasised, the cross she had had to bear, even although as a young child the pain also kept Ashcroft awake: "all the relatives were so sorry for my mother, because she nursed my dad for years, as I say, and it was hard. I can remember having difficulty getting to sleep because he was on morphia, and he was moaning in the next bedroom - as I say, a little cottage." 66 Ashcroft's closing reference intimates how much she was affected by her father's distress, but she frames the trauma as one experienced primarily by her mother.

Scates also carried a sense of injury on her mother's behalf. This came across as she broke down when describing a Christmas when her father was hospitalized and the Ministry of Pensions deducted funds from his pension to pay for his maintenance, leaving the family impoverished. ${ }^{67}$ On hearing the story at the time I thought she was reporting a scene she had witnessed herself. Only on listening to it later did it become apparent that this was a received memory, her mother's experience rather than her own: 
KS: So we never actually starved, but we didn't even ... sometimes, have any bread ... er ... though my mother could make bread if we had flour. And anyway, came Christmas, and we'd gone to bed, and there was a knock at the door - but, of course, we didn't know, I was sound asleep, I think - and at the door stood a chauffeur, and he had a sack, and he had boxes, and there was also a valet, all dressed up in uniform, you know, from the household ... er ... it was the Brown Owl's family, and she must have said to the others, you know, "We've got this family here, and we've got to do something". So they did. And we all got a present at Christmas, and we ... er ... had a roast dinner ... er ... everything that we wanted for Christmas was there. And coal! And ... er ... (laughs) ... oh yeah, what my mother ... erm ... affected her more than anything, was not that these things came from this wealthy family, was that the chauffeur came back, and he pressed sixpence in her hand, and he was hard up, and he'd got children ... and I think that upset her more than anything. Anyway, I can see it all! (starts to cry)

Anyway, Dad came home on Christmas Day ... all wrapped up in a blanket, and so we had a good Christmas. I don't know how they managed ... so we went up, and we went down. (stops crying)

Now, I want you to see this, because every now and again, my father kept having a letter saying, "Come and be examined", because they tried to take away his pension, because they found out that he could dig the garden and grow vegetables...(pushes a Ministry of Pensions letter towards me)

MR: I'll read this out then, shall I ${ }^{68}$ 
As Kathleen was crying I felt she was in her mother's shoes: it was her mother's humiliation and gratitude that she was feeling, to such an extent that, although she had not witnessed the scene herself, nevertheless "I can see it all!" She feels anger towards the Ministry of Pensions on her parents' behalf, particularly her sick father who each year had to parade himself before the pension officials and account for his disabilities. That anger has travelled across generations and time, perhaps becoming more intense in retrospect, the improved pension provision for soldiers since the Second World War making the treatment of her father appear more harsh and mealy-mouthed in retrospect. As Kathleen pushed the pensions letter towards me to read out, I felt a sense of outrage at the anonymous government official who had added to the stresses of a mentally and physically frail father, a case of transmission from parents to children and then to the interviewer, eighty years on from the event. This is primary identification, where the children live with the distress of parents long after their deaths.

There were moments in the interviews when I sensed some frustration and disappointment that their childhoods had been more difficult than some, but such feelings were usually rather cloaked. They could be expressed in accounts of financial hardship, Maloney, for example, contrasting his family's fate with that of his uncle, who became a senior RAF officer after the war, lived in a grand house and sent his two boys to private schools. "My life should have followed a similar pattern ... erm ... but it didn't," he explained ruefully. ${ }^{69}$ Starr's family was absorbed in just getting by:

... I think one of the things arising out of the whole thing was that we never grew up with any expectations, you know. I think ... I mean, one of my faults, I think, is I never really had any ambitions or expectations, and you just accept things as they come. I think that may be partly due to the way we lived, I don't know ... because, like, you know ... I regret now, not having a better education. Erm ... but ... erm ... 
as I say, these things were never talked or discussed about in any way really, you just accepted everything. ${ }^{70}$

Starr had not known what it meant for a child to be at the centre of its parents' concerns; early on he had learned not to put himself first, but to "just accept things."

Starr here articulates the negative personal impact of the generational reversal here, but for others, such questioning felt disloyal and instead they emphasised the importance of not complaining, and being helpful. These qualities were encouraged from an early age, as Ashcroft explained: "She had it very hard, and I think all the relatives drummed it into us, 'Look after your mother, Marion, because she's had it so hard.' I think we just knew we had to look after her. I just accepted the fact. I never resented her. But ... we got on well.",71 Ashcroft was keen to explain to me that she did not resent the pressures that her relatives and brother placed on her to look after her mother. Yet her very assurances sometimes point to different feelings about her childhood. On listening again to Ashcroft's interview I noticed her habit of repeating the word "deprived," always however in a context of explaining that she herself had not been deprived:

She was very very good. I was lucky. I don't have visions of a ... erm ... a deprived childhood. We had no money, but we had everything that mattered. She was very loving, very kind, very capable, and I had good grandparents. ${ }^{72}$

And I actually had a holiday every year... I've had holidays at York a lot, Skipton a lot - that's where her sisters were - and so, as I say, don't imagine it was a deprived childhood, it wasn't. ${ }^{73}$

she was thrilled with the ... winter coat he got [a gift to her brother for grammar school].... it was very good quality - and this was all paid for by the British Legion, 
because my dad had been an Army man, you see. But as I say, don't think of it as a deprived childhood, I wasn't. We had everything that matters. ${ }^{74}$

It wasn't a deprived childhood at all. He met us from school every day. He had a sweet in his pocket for me, “Don't tell your mum, because she says I'll spoil your dinner!"75

At no point in the interview did I ask Ashcroft if she felt deprived, yet it seems to have been a question in her mind, in each case, however, eliciting a response that emphasised the love and support she received from her mother, her grandparents and aunts, relatives, and father. She had grown up in the North-East between the wars, when unemployment rates were high and many families would have faced severe poverty. Her mentions of holidays, coat and sweets, suggest that she is thinking partly of deprivation in material terms, such as she might expect a social historian to be interested in. Yet there are other aspects to how she conceives of deprivation which are as much emotional as material, such as a mother who even despite having to nurse her father's wounds and support the family financially, could be "very loving," and a father whose presence around the house when she was young had given her many tender memories.

Whose voice is it telling Ashcroft that hers was not a "deprived childhood"? Was it the voices of neighbours and relatives which she has internalised? Why does she repeat this phrase, and emphasise her memories of loving parents and supportive neighbours? Perhaps this is a kind of reaction formation, an underlying feeling that she wanted for something being countered by her insistence that she was not a victim. This is the characteristic psychological situation of the second generation, whose memories re-enact a sense of being on the margins. As neighbours and relations would remind them, their difficulties were not as great as those of their fathers and mothers. 
We might then reverse Ashcroft's injunction, and ask what was taken away from her in childhood. Her father had died on her ninth birthday, she explained, "Yes, my ninth birthday, because I couldn't have a party. We always had a birthday party, but I couldn't have one that year." ${ }^{, 76}$ As Ashcroft explains in the quotation at the beginning of this chapter, she had found it hard to cry after her father and brother's death. The family script was one of not giving in to grief, of continuing to work and keep active, because work provided a positive identity and survival depended on not giving way. It was a script that gave the disabled soldier's family respect in the community. Ashcroft recalled the time when her brother broke his arm and fainted after the local doctor tried to move it about: "He said, 'Oh, Good Lord, lad! You haven't got the guts your father had!' And Eric was livid! He said, 'I wonder how he would like his broken arm lifted up over his shoulder!' But my dad was wellrespected. And my mother ... she was." The family's ability to bear suffering was admired among the local community, it earned them respect and became an identity. ${ }^{77}$

The patent theme of Ashcroft's story was of a loving mother who had coped well despite the loss of her husband and first son, and was well supported by neighbours and relatives. It was thus a childhood which was not deprived, and yet this version of the family history made it difficult to express how the loss of her father and brother had affected her. The word 'deprived' exposes the legacies in Ashcroft's life between a childhood experience of grief and the family script of maternal grief and getting by.

\section{Conclusion}

Because of the long-term effects of incapacity, and because British war pensions rarely matched the earnings of able-bodied men and were sometimes unavailable, many children of disabled soldiers grew up amidst financial hardship and emotional stress. The family culture 
was one in which children were encouraged to help out and not cause worry. There were also emotional implications for the children because of the way that disability challenged conventional ideas of parenting. They had to accommodate the limitations of their fathers amidst an interwar ideal of fathers as physically active and family breadwinners. Mothers were often central to the family's material and emotional security, and as a result the children tended to develop a strong sense of empathy towards her. This primary identification with mothers was recapitulated in the interviews as the children described her struggles and achievements, at times presenting a de-centred narrative as if through her eyes. The exhaustion, loss, humiliation and anger of parents - and mothers in particular - was carried by the children. Even in old age, they found it difficult to express negative feelings about the way fathers' disabilities had dominated family life, or the importance that friends and relatives had placed on supporting their mothers.

The children in this study grew up on the cusp of two rather different emotional worlds. In many ways their childhoods were similar to those of working-class and poor children in Britain in the early to middle twentieth century. They often understood that they were an additional burden on their parents, and they learned early on to alleviate the burden, helping around the house, curtailing their ambitions for education, and contributing to family income. Yet the children of disabled soldiers faced additional emotional pressures, living with the sight, smell and pain of wounds, the fallout of a war waged before their time. Nevertheless, they did not look back on their childhoods in a wholly negative light and indeed many stressed the positive aspects of learning about the world of the blind veteran or amputee and becoming competent at looking after themselves and others from an early age. For some the sense of having not only survived, but coped successfully with these difficulties, was an important part of their self-identity. 
The interviewees looked back on their childhoods in the light of later family histories, which, by and large, were less dominated by pressures of economic subsistence, and in which greater recognition was given to the emotional states of children. These more psychological conceptions of childhood began to emerge between the wars. From progressive education and the development of social work, child psychology and juvenile delinquency, through to advice columns in women's magazines, the notion that the child's well-being depended on emotionally attentive parents, was gaining ground among child experts and liberal-minded sections of the middle-class in the 1920 s and 30s. ${ }^{78}$ After the Second World War, such ideas became widespread within both public policy and popular belief. ${ }^{79}$ For the children of disabled soldiers the First World War thus formed the backdrop of a divided world. They grew up in a family culture of not complaining or making demands on parents, but became adults and parents at a time when public discourses about family life increasingly emphasised the emotional freedom of childhood and the psychological responsibilities of parents.

I would like to thank Pieter Verstraete, Sean Nixon, and the editors of this volume, Jason Crouthamel and Peter Leese for their helpful comments on this chapter.

\footnotetext{
${ }^{1}$ Doris Lessing, Under My Skin. Volume One of My Autobiography, to 1949 (London: Virago, 1994), 10.

2 Deborah Cohen, The War Come Home: Disabled Veterans in Britain and Germany, 19141939 (Berkeley: University of California Press, 2001), 4; Jessica Meyer, Men of War-Masculinity and the First World War in Britain (Basingstoke: Palgrave, 2009), 97.

${ }^{3}$ Peter Barham, Forgotten Lunatics of the Great War (New Haven: Yale, 2004), 4.
} 
${ }^{4}$ See Fiona Reid on the difficulties of ascertaining numbers. Broken Men: Shell Shock, Treatment and Recovery in Britain, 1914-1930 (London: Continuum, 2010), 10; Jay Winter on shell-shock casualties, BBC Radio 4 programme 'All in the Mind', 6/5/14, http://www.bbc.co.uk/programmes/b042jn7j. As Marina Larsson notes, 'It is to the everyday lives of ex-servicemen, rather than the statistics, that we must look for the impact of disability in all its diversity.' Shattered Anzacs. Living with the scars of war (Sydney: University of New South Wales Press, 2009), 19.

${ }^{5}$ The interviewees responded to a newspaper request for help with research on the impact of the First World War on families in the 1920s and 30s. The interviews were around two hours long and focused on childhood and home life, covering topics such as housing and local neighbourhoods, diet and clothing, how families supported themselves financially and spent their leisure time, as well as relationships with parents, siblings and wider kin. My aim was to try and elicit material about the effects of the war through accounts of the domestic setting.

Interviewing people about the personal impact of events before their time raises complex issues about method which I hope to pursue in a later publication. Concerned as it is with emotional legacies of the war, the project considers testimony as both a retrospective construction, as has become the norm in recent decades in oral history work, and as a source of childhood emotional experience, the effects of which surface may wittingly and unwittingly in the interviews.

${ }^{6}$ Jessica Meyer, “"Not Septimus Now”: Wives of Disabled Veterans and Cultural Memory of the First World War in Britain,” Women's History Review, Vol. 13:1, 2004, 120.

${ }^{7}$ Larsson, Shattered Anzacs, 130.

${ }^{8}$ Ellen Ross, Love and Toil. Motherhood in Outcast London 1870-1918 (Oxford: Oxford University Press, 1993); Melanie Tebbutt, Women's Talk? A Social History of 'Gossip' in Working Class Neighborhoods 1880-1960 (Aldershot, Hants.: Scolar Press, 1995). Within the 
middle-classes, conceptions of public duty and the belief that introspection would sap morale and was psychologically damaging could lead to a similar emphasis on the stiff upper li

${ }^{9}$ Cohen, War Come Home; Reid, Broken Men.

${ }^{10}$ Julie Anderson, War, Disability and Rehabilitation in Britain: "Soul of a Nation"

(Manchester: Manchester University Press, 2011), 7.

${ }^{11}$ Larsson, Shattered Anzacs, 23.

${ }^{12}$ Dan Bar-On, Fear and Hope: Three Generations of the Holocaust (Cambridge: Harvard University Press, 1995); Ilany Kogan, 'The Second Generation in the Shadow of Terror', in M. Gerard Fromm, ed., Lost in Transmission. Studies of Trauma across the Generations (London: Karnac, 2012); M. Hirsch, The Generation of Postmemory. Writing and Visual Culture after the Holocaust (New York: Columbia University Press, 2012).

${ }^{13}$ Kogan, 'Second Generation', 5-8.

${ }^{14}$ Haydée Faimberg, The Telescoping of Generations - Listening to the Narcissistic Links between Generations (London: Routledge, 2005).

${ }^{15}$ Ashcroft transcript, 13.

${ }^{16}$ Cohen, War Come Home, p. 4; Meyer, Men of War, pp. 99-103; Peter Leese, 'Problems Returning Home: The British Psychological Casualties of the Great War', The Historical Journal, 40:4, Dec. 1997, 1056.

${ }^{17}$ Anderson, 49-52. Meyer comments that those with mental illnesses were least likely to receive government assistance as their disabilities were invisible and more open to challenge. See "Not Septimus Now," 120.

${ }^{18}$ Anderson, War, Disability and Rehabilitation 61.

${ }^{19}$ Cohen, War Come Home, Chapter 3, "Life as a Memorial," 101-49.

${ }^{20}$ Ashcroft transcript, 33 . 
${ }^{21}$ The British State only provided pensions for 'familial responsibilities' that pre-existed a man's disablement. The pension was not increased if an already disabled man fathered a child. Thus a single man and a man married after disablement with dependents received the same pension. A woman who married a man after his disablement, moreover, was not entitled to a widows' pension on his death. The Ministry of Pensions' rationale for not supporting wives this was twofold, firstly the expense, and secondly the fear that ex-servicemen would fall prey to 'veteran-marrying speculators.' Cohen, War Come Home, 106-7.

${ }^{22}$ Cohen, War Come Home. Leese notes that in the immediate post-war years, returnees frequently felt 'resentful of inadequate government policies and petty-minded officials.' Leese, 'Problems Returning Home', 1066.

${ }^{23}$ Ashcroft transcript, 14 .

${ }^{24}$ Hera Cook, "From Controlling Emotion to Expressing Feelings in Mid-Twentieth Century England," Journal of Social History, 47:3, 2014, 635.

${ }^{25}$ Larsson, Shattered Anzacs, 131.

${ }^{26}$ Ashcroft transcript, 28; 27.

${ }^{27}$ Ashcroft transcript, 2.

${ }^{28}$ S. Brooke, "Gender and Working Class Identity in Britain during the 1950s," Journal of Social History 34:4, 2001, 774; L. Davidoff, M. Doolittle, J. Fink and K. Holden, eds., The Family Story. Blood, contract and intimacy, 1830-1960 (Harlow, Essex: Longman, 1999), 195. On male domesticity in mid-century Britain see Joanna Bourke, Working-Class Cultures in Britain. Gender, Class and Ethnicity (London: Routledge, 1994), 81-9.

${ }^{29}$ Larsson, Shattered Anzacs, 126; David Gerber, 'Introduction: Finding Disabled Veterans in History, in D. Gerber, ed., Disabled Veterans in History (Michigan: Michigan University Press, 2012), 9.

${ }^{30}$ Prescott transcript, 3. 
${ }^{31}$ See Larsson on the children's 'heightened awareness' of the father's state. Shattered Anzacs, 132.

${ }^{32}$ Borden transcript, 4.

${ }^{33}$ Anderson, War, Disability and Rehabilitation, 52.

${ }^{34}$ See Gerber for an interesting discussion of the cultural resonance of fear and valour in representations of the disabled veteran. 'Introduction', 5-8

${ }^{35}$ Starr transcript, 17.

${ }^{36}$ Pudney transcript, 8 .

${ }^{37}$ Starr transcript, 27. A Charity Organisation Society visitor's report on Starr's father noted his poor quality of life: "He can very seldom get out of his own apartment and his life is consequently extremely monotonous and dull." Quoted in Cohen, War Come Home, 108-9.

${ }^{38}$ Starr transcript, 14, 33.

${ }^{39}$ Maloney transcript, 20, 17.

${ }^{40}$ Maloney transcript, 35-6.

${ }^{41}$ Maloney transcript, 6, 34, 7.

${ }^{42}$ Pudney transcript, 2.

${ }^{43}$ Pudney transcript, 3.

${ }^{44}$ Meeks transcript, 18, 20.

${ }^{45}$ Scates transcript, 27.

${ }^{46}$ Pudney transcript, 8, 5 .

${ }^{47}$ Pudney transcript, 19, 9.

${ }^{48}$ Tebbutt, Women's Talk, 109-111.

${ }^{49}$ Maloney transcript, 1 .

${ }^{50}$ Meeks transcript, 17.

${ }^{51}$ South transcript, 8-9. 
${ }^{52}$ Meeks transcript, 20.

${ }^{53}$ Ashcroft transcript, 3.

${ }^{54}$ Penny Summerfield notes similar kinds of conflicts between parents and daughters over joining up during the Second World War. Reconstructing Women's Wartime Lives

(Manchester: Manchester University Press, 1998), Ch. 2, 42-75.

55 Prescott transcript, 14.

${ }^{56}$ Gates transcript, 27.

${ }^{57}$ Gates transcript, 30 .

${ }^{58}$ Ashcroft transcript, 10.

${ }^{59}$ Ashcroft transcript, 11.

${ }^{60}$ Prescott transcript, 21.

${ }^{61}$ Prescott transcript, 46, 49.

${ }^{62}$ Elizabeth Roberts, A Woman's Place: an Oral History of Working-class Women, 18901940 (Oxford: Polity, 1984); Women and Families: an Oral History, 1940-1970 (Oxford:

Polity, 1995).

${ }^{63}$ Ashcroft transcript, 15-16.

${ }^{64}$ Ashcroft transcript, 16.

${ }^{65}$ Meeks transcript, 20.

${ }^{66}$ Ashcroft transcript, 16.

${ }^{67}$ See Jessica Meyer on veterans' anger at the policy of making deductions for maintenance.

Men of War, 117.

${ }^{68}$ Scates transcript, 17.

${ }^{69}$ Maloney transcript, 3.

${ }^{70}$ Starr transcript, 65 .

${ }^{71}$ Ashcroft transcript, 16-17. 
${ }^{72}$ Ashcroft transcript, 6.

${ }^{73}$ Ashcroft transcript, 6.

${ }^{74}$ Ashcroft transcript, 10.

${ }^{75}$ Ashcroft transcript, 28.

${ }^{76}$ Ashcroft transcript, 18.

${ }^{77}$ Ashcroft transcript, 18.

${ }^{78}$ By 1940, notes Harry Hendrick, children were seen to have 'a greater sense of depth' than at any previous time. Child Welfare: England, 1872-1989 (Bristol: Policy Press, 2003), 5. See also Michal Shapira, The War Inside: Psychoanalysis, Total War, and the Making of the Democratic Self in Postwar Britain (Cambridge: Cambridge University Press, 2013), Ch. 1, 24-48; Cathy Urwin and Elaine Sharland, "From Bodies to Minds in Childcare Literature: Advice to Parents in Inter-War Britain," in Roger Cooter, ed., In the Name of the Child: Health and Welfare, 1880-1940 (London: Routledge, 1992), 174-199; Deborah Thom, "Wishes, Anxieties, Play and Gestures: Child Guidance in Inter-War England," in Cooter ed., In the Name of the Child, 200-219; Mathew Thomson, Psychological Subjects: Identity, Culture, and Health in Twentieth-century Britain (Oxford: Oxford University Press, 2006). ${ }^{79}$ Roberts, Women and Families, 234-6. This too was partly a legacy of the First World War, as studies of shell-shock victims gave way during the early 1920s to the development of research on the emotional lives of infants and children. Michael Roper, "From the Shellshocked Soldier to the Nervous Child: Psychoanalysis in the Aftermath of the First World War," Psychoanalysis and History, 18:1, 2016, 39-69. 